\title{
1 Amplification of 16S rDNA reveals important fish mislabeling in Madrid
}

\section{2 restaurants}

3 Jose L. Horreo ${ }^{1 *}$, Patrick S. Fitze', Alberto Jiménez-Valverde ${ }^{2}$, Jorge Ari Noriega', Maria

$4 \quad$ L. Pelaez

5 'Department of Biodiversity and Evolutionary Biology, National Museum of Natural

6 Sciences (MNCN-CSIC), Calle José Gutiérrez Abascal 2, 28006 Madrid, Spain.

$7 \quad$ 2Departamento de Ciencias de la Vida, Edificio de Ciencias, Universidad de

8 Alcalá, Campus Universitario, 28871 Alcalá de Henares, Spain.

9 *Corresponding author E-mail address: horreojose@gmail.com (J. L. Horreo)

\section{ABSTRACT}

12 Food fraud encompasses economic fraud and can produce health problems for consumers, as well as conservation problems for the involved species. Nevertheless,

14 few studies tested for mislabeling in restaurants. In this study, we tested for mislabeling 15 of fish species in restaurants. We sampled 77 fish dishes from 53 different restaurants located in 9 different districts of Madrid, Spain. A short fragment of the 16S rDNA was employed for DNA amplification leading to species or genera identification. Results showed that 7 species or genera and almost $30 \%$ of the samples were mislabeled. Mislabeling was present in $37 \%$ of the sampled restaurants and in $71 \%$ of the sampled districts. Mislabeling was common and it was not correlated with a districts' economic status (i.e. with the official average square-meter price of apartments). The analyses also showed that some species were more prone to be mislabeled than others.

Keywords: 
25 16S rDNA; genetic identification; food control; fraud; mislabeling; species

26 authentication.

27

28 
Food fraud can have important consequences for consumers (e. g. Spink \& Moyer,

2011). The most obvious consequences for consumers are of economic nature.

Intentional adulteration of food usually provides the vendor with a financial advantage, what is known as 'Economic Motivated Adulteration (EMA) of food' (Everstine, Spink, \& Kennedy, 2013). Another consequence is the inadvertent consumption of species, which can produce serious health problems (Triantafyllidis, et al., 2010), and that may even lead to intoxication (e.g. with TTX; Giusti, et al., 2018). Last but not least, food fraud can also produce important problems for species conservation (e.g. Ward, Holmes, \& Last, 2008), since it includes protected species, endangered species and species with capture quota. In these cases, food fraud generally masks the illegal exploitation (Horreo, Machado-Schiaffino, \& Garcia-Vazquez, 2017; Pramod, Nakamura, Pitcher, \& Delagran, 2014). Food fraud must be avoided, and its detection and the knowledge about how, where, and when food fraud occurs, is the first step to control it. Seafood is extremely important in the European Union (EU). For example in 2015, the EU seafood supply (domestic production and import) reached more than 14.5 million tons, and households spent 54.8 billion Euros on seafood from fisheries and 47 aquacultures (EUMOFA, 2017). Food fraud usually occurs due to financial incentives (von der Heyden, Barendse, Seebregts, \& Matthee, 2010), and it can be detected using cost-effective, DNA based analytical methods (Tinacci et al. 2018). Fish fraud can happen during catching, at the wholesaler, during processing (Muñoz-Colmenero, Blanco, Arias, Martinez, \& Garcia-Vazquez, 2016), in end-user markets (Muñoz-

52 Colmenero, et al., 2015) or in restaurants. In restaurants, the percentage of mislabeling 
2015), but few studies exist so far and specific studies are required in order to confirm these suggestions (Pardo, Jiménez, \& Pérez-Villarreal, 2016, Pardo, et al., 2018). In order to detect fish fraud, the fish species indicated on the product label (bought in a shop/supermarket/supplier/restaurant) can be compared with the fish species revealed by genetic analyses (e.g. Muñoz-Colmenero, et al, 2016). Fish can be mislabeled along the entire supply chain, i.e. when indicating where it was caught (in which geographic area, in the sea, or in a fish farm), during the acquisition of intermediate buyers, during processing, up to the place where the end-user buys it. This makes the origin of mislabeling difficult to track. For example, a restaurant may unintentionally purchase a wrongly labeled species, it may unintentionally use the wrong fish for preparing a meal, or it may intentionally change the species' name to increase his benefits (Kappel \& Schröder, 2016), thereby defrauding the restaurant's guests. The detection of mislabeling is very important in order to alert and act against no-ethic and illegal behavior but unfortunately, as commented above, studies investigating mislabeling in restaurants are scarce.

Madrid is the capital of Spain (Europe) and Spain is the country with the highest household expenditure for fisheries and aquaculture in the European Union (EUMOFA, 2017). Three million inhabitants live in the center of the city and Madrid is Europe's $2^{\text {nd }}$ biggest city. Madrid is one of the world's most touristic capitals, with more than 5.5 million tourists visiting Madrid per year (International, 2017). The hostelry is very important and the city center consists of 2,862 restaurants and 3,307 bars (Servilab, 2010) and to our knowledge, no studies assessed the prevalence of food fraud in this city except in grouper (Asensio, 2008). In this study, we tested for mislabeled food and measured the prevalence of mislabeling in fish by comparing whether species and genera indicated on a label coincided with the fish species unraveled by genetic 
methods. Anonymous clients took tissue samples from fish meals in several restaurants located in different districts/areas in the city of Madrid and species identification was done employing DNA amplification and BLAST analysis. Results will provide evidence for the existence or absence of fish mislabeling in restaurants of one of the biggest cities of Europe.

\section{Materials and Methods}

\section{$\underline{2.1 \text { Sampling }}$}

A total of 77 different fish samples (Table 1) were taken from meals served in 53 different restaurants located in 9 different districts of the city of Madrid: Arganzuela, Carabanchel, Centro, Chamartín, Chamberí, Latina, Moncloa, Salamanca and Tetuán. The average apartment price (Euro per square meter) of each of these districts was employed as an indicator of the district's economic level. Average apartment prices were obtained from the Madrid city council (http://www.madrid.es; accession date: 18 July 2018).

Employed fish samples included 17 different species or genera, depending on menu label. The number of samples per restaurant ranged between 1 and 7 . Anonymous people acted as clients in those restaurants during the years 2017 and 2018 and sampled tissue from served dishes, including fresh fish, tataki, tartar, carpaccio, ceviche, sashimi, and coated and/or fried fish. The restaurant, the fish name appearing in the menu and the sampling date were annotated. Samples were put into Eppendorf tubes and stored frozen until laboratory analyses.

\section{$\underline{2.2 \text { Genetic analyses }}$}


104 Kit (Qiagen; Verlo, Netherlands). A primer pair amplifying a short fragment (75-125 basepairs, approximately) of the 16S rDNA was employed for DNA amplification. This gene has been demonstrated to allow for reliable species authentication, even in highly degraded samples (Horreo, et al., 2012; Muñoz-Colmenero, Martinez, Roca, \& GarciaVazquez, 2016), and in canned pet food (Armani, et al., 2015). Given that the real processing of the samples (from the supplier until it appears on the dish) collected for this study is unknown, and given that the effective processing may not coincide with what is written on the menus, we used this fragment for species identification. The amplification of this fragment assures that the used genetic tools are highly sensitive, and that they will detect species or traces of species present in dishes with a high probability. Consequently, primers $16 \mathrm{~S}-\mathrm{HF}$ and 16S-HR were used. PCR conditions included a total volume of $25 \mu \mathrm{L}$ containing $1 \mu \mathrm{L}$ DNA, $12.5 \mu \mathrm{L}$ DreamTaq Master Mix Polimerase (Thermo Fisher Scientific; Beverly, USA), $1 \mu \mathrm{L}$ of each primer (10uM) and $72^{\circ} \mathrm{C}$ for $60 \mathrm{~s}$, and a final extension at $72^{\circ} \mathrm{C}$ for $10 \mathrm{~min}$. PCR products were then purified and finally run on an ABI 3100 sequencer (Applied Biosystems; Foster city, USA). DNA sequences were viewed and edited with the BioEdit alignment editor software 122 (Hall, 1999).

\subsection{Species identification}

125 The European Regulation (EU) 1379/2013 establishes which information needs to be 126 declared when selling seafood at the retailer or mass caterer. Each EU Member State 127 has to draft an official list with the trade names (including scientific, local or regional 
names). These names are the names that need be officially used as product labels in the

129

130

131

132

133

134

135

136

137

138

139

140

141

142

143

144

145

146

147

148

149

150

entire country. The Spanish Ministry of Agriculture, Food and Environment published this list on April 10th, 2014 (BOE-A-2014-3865). The names on this list were employed in this work in order to determine the scientific name that corresponds to each of the menu labels (Table 1). All menu labels detected in this study existed on the official list published by the Spanish Government, only with the exception of "pez mantequilla" (samples S18 and S19), which did not appear in the legislation valid during the samplings (BOE-A-2014-3865). Consequently such samples were deleted from the analyses.

Sequence comparison for species identification was done with the BLAST utility (https://www.ncbi.nlm.nih.gov/BLAST) of the GenBank public database. To this end, we first corroborated that the $16 \mathrm{~S}$ rDNA sequence of the species indicated on the menu label was present in Genbank (https://www.ncbi.nlm.nih.gov/genbank). Thereafter, BLAST was used to find the most similar sequence. Successful identification existed if the sequence amplified from the collected tissue exhibited a similarity of $100 \%$ with a sequence present in GenBank, following Armani, et al., (2015). If the most similar sequence rendered by BLAST corresponded to a species/genera that did not coincide with the species/genera mentioned on the menu, we classified the sample as being mislabeled. In these cases, an additional BLAST comparison was done with the DNA sequence of the sample $v s$. the DNA sequence of the taxa mentioned on the menu to test for the robustness of our classification.

\section{$\underline{2.4 \text { Economic level of Madrid districts }}$}


and the percentage of mislabeling. Only districts with two or more samples were included in the Spearman's rank correlation.

\section{Results and discussion}

156 All fish samples were successfully amplified. Fragment sizes ranged between 76 and 157122 base pairs, which was enough to identify mislabeling on the species/genera level mentioned on the restaurant's menu (Table 1), demonstrating the usefulness of the employed primers even in cooked and processed food. In total, 32 samples exhibited a

160 similarity of $100 \%$ with the species mentioned on the menu, and mislabeling appeared in $28.12 \%$ of the these samples and in $37.5 \%$ of the restaurants. Moreover, using Kappel and Schröder (2016) 2\% cut-off threshold (i.e. a sequence identity of $\geq 98 \%$ ), mislabeling appeared in $36 \%$ of the samples. The here detected proportions of mislabeling do not differ among used thresholds $\left(\chi^{2}=0.62, P=0.43\right)$ and they are similar to the percentage recently found in Metro Vancouver, Canada (29\%; Hu, Huang, Hanner, Levin, \& Lu, 2018). Moreover, it is within the range found in European mass caterings (Pardo, et al., 2018). The high proportion of mislabeling demonstrates that a more effective control and/or management is required in order to avoid mislabeling and fraud. This is especially important, since among other reasons mislabeling exists for economic issues, and since it can produce health and conservation problems (Everstine,

171 et al., 2013; Pramod, et al., 2014; Triantafyllidis, et al., 2010). The detected amount of mislabeling is conservative for several reasons. First, we

173 sampled all kind of fish, although one would predict that fraud and thus mislabeling would be most prevalent in expensive species that are difficult to get, e.g. in Epinephelus marginatus. Previous studies detected a much higher percentage of 
mislabeling, namely $47.1 \%$ in the expensive grouper (Epinephelus marginatus;

177 Asensio, 2008), 43\% of mislabeling in hake in Spain (Muñoz-Colmenero, Blanco, et al., 178 2016), and up to 50\% of mislabeling of hake in German restaurants (Kappel \&

179 Schröder, 2016). Second, in this study we sampled restaurants only once and only a few

180 plates per restaurant (average number of plates sampled per restaurant $=1.42 \pm 0.13$ standard error), what reduces the chance of detecting mislabeled species. All these facts suggest that the percentage of mislabeled fish species/genera reported in the present study are conservative and likely underestimate the actual level of mislabeling and 184 fraud.

7 species/genera names appearing on the menu were mislabeled (which corresponds to $43.75 \%$ of the sampled menu labels; Fig. 1), and these names correspond to the following species: Stizostedion spp., Scophtalmus maximus, Merluccius merluccius, Lepidorhombus boscii, Galeorhinus galeus, Epinephelus marginatus, and Gadus spp. (see BOE-A-2014-3865). Interestingly, some of the species/genera names appearing on the menu were consistently wrong and were thus fraudulent in all sampled cases. The two restaurants in which we supposedly consumed Epinephelus marginatus, actually sold two different fish species. In contrast, in other species the name on the menu consistently coincided with the real species, e.g. in Micromesistius poutassou

194 (three samples from three different restaurants were correctly labeled). This suggest that some species are more prone to fraud than others, and that species subjected to fraud were substituted by several different species. This information is important in order to unravel the source of mislabeling and fraud and for developing management actions in relation to seafood fraud. If all restaurants sell a given species under a wrong name, it is more likely that mislabeling and fraud happen before the restaurants buy the fish, while 
strong differences in the substitution among restaurants point to restaurant-specific tactics. only one district, Carabanchel, mislabeling was absent, but it had only one sample. The detected percentage of mislabeling was not correlated with the apartment prices of the district where the sampled restaurant was located $\left(n=6, r_{s}=-0.77, p=0.10\right)$. This result suggests that mislabeling is widely extended and independent of the economic level of the district in which the restaurants are located. However, a more extensive sampling is required to corroborate this result.

\section{Conclusions}

In conclusion, mislabeling of fish sold in restaurants in Madrid is important since it concerned $28.12 \%$ of the sampled fish dishes. It is more common in some fish species than in others and it is present in the majority of the districts of the city independently of their economic level, pointing to fraud at different levels of the sales hierarchy (restaurant and wholesaler).

217

\section{Acknowledgements}

219 We thank to all the people that acted as anonymous samplers. María Luisa del Pozo Polo (Systematics Laboratory of the MNCN) was helpful with laboratory analyses. 


\section{References}

227

228

229

230

231

232

233

234

235

236

237

238

239

240

241

242

243

244

245

246

247

248

249

250

251

252

253

254

255

256

257

258

259

260

261

262

263

264

265

266

267

268

269

270

271

Armani, A., Tinacci, L., Xiong, X., Castigliego, L., Gianfaldoni, D., \& Guidi, A. (2015). Fish species identification in canned pet food by BLAST and Forensically Informative Nucleotide Sequencing (FINS) analysis of short fragments of the mitochondrial 16s ribosomal RNA gene (16S rRNA). Food Control, 50, 821-830.

Asensio, L. (2008). Application of multiplex PCR for the identification of grouper meals in the restaurant industry. Food Control, 19, 1096-1099.

Bérnard-Capelle, J., Guillonneau, V., Nouvian, C., Fournier, N., Le Loët, K., \& Dettai, A. (2015). Fish mielabelling in France: substitution rates and retail types. PeerJ, 2, e714.

Everstine, K., Spink, J., \& Kennedy, S. (2013). Economically Motivated Adulteration (EMA) of food: common characteristics of EMA Incidents. Journal of Food Protection, 76, 723-735.

EUMOFA (2017). European Market Observatory for Fisheries and Aquaculture Products. European Commission.

García-Jiménez R., Horreo J.L., Valdecasas A.G. (2017) Minimal barcode distance between two water mite species from Madeira Isand: a cautionary tale. Experimental and Applied Acarology, 72, 133-143.

Giusti, A., Ricci, E., Guarducci, M., Gasperetti, L., Davidovich, N., Guidi, A., \& Armani, A. (2018). Emerging risks in the European seafood chain: Molecular identification of toxic Lagocephalus spp. in fresh and processed products. Food Control, 91, 311-320.

Hall, T. A. (1999). BioEdit: a user-friendly biological sequence alignment editor and analysis program for Windows 95/98/NT. Nucleic Acids Symposium Series, 41, 95-98.

Horreo, J. L., Ardura, A., Pola, I. G., Martinez, J. L., \& Garcia-Vazquez, E. (2012). Universal primers for species authentication of animal foodstuff in a single polymerase chain reaction. Journal of Science of Food and Agriculture, 93(2), 354-361.

Horreo, J. L., Machado-Schiaffino, G., \& Garcia-Vazquez, E. (2017). Forensic assignment to geographic origin, a useful tool in seafood fraud control. Forensic Science International, 272, 37-40.

Hu, Y., Huang, S. Y., Hanner, R., Levin, J., \& Lu, X. (2018). Study of fish products in Metro Vancouver using DNA barcoding methods reveals fraudulent labeling. Food Control, 94, 38-47.

International, E. (2017). Top 100 City Destinations Ranking. In. London.

Kappel, K., \& Schröder, U. (2016). Substitution of high-priced fish with low-priced species: adulteration of common sole in German restaurants. Food Control, 49, 478-486.

Muñoz-Colmenero, M., Blanco, O., Arias, V., Martinez, J. L., \& Garcia-Vazquez, E. (2016). DNA authentication of fish products reveals mislabeling associated with seafood processing. Fisheries, 41, 128-138.

Muñoz-Colmenero, M., Klett-Mingo, M., Díaz, E., Blanco, O., Martinez, J. L., \& Garcia-Vazquez, E. (2015). Evolution of hake mislabeling niches in commercial markets. Food Control, 54, 267-274. 
Muñoz-Colmenero, M., Martinez, J. L., Roca, A., \& Garcia-Vazquez, E. (2016). Authentication of commercial candy ingredients using DNA PCR-cloning methodology. Journal of Science of Food and Agriculture, 96, 859-867.

Neter, J., Kutner, M. H., Nachtsheim, C. J. \& Wasserman, W. (1996). Applied Linear Statistical Models, Irwin, Illinois.

Pardo, M. A., Jiménez, E., \& Pérez-Villarreal, B. (2016). Misdescription incidents in seafood sector. Food Control, 62, 277-283.

Pardo, M. Á., Jiménez, E., Viðarsson, J. R., Ólafsson, K., Ólafsdóttir, G., Daníelsdóttir, A. K., \& Pérez-Villareal, B. (2018). DNA barcoding revealing mislabeling of seafood in European mass caterings. Food Control, 92, 7-16

Pramod, G., Nakamura, K., Pitcher, T. J., \& Delagran, L. (2014). Estimates of illegal and unreported fish in seafood imports to the USA. Marine Policy, 48, 102-113.

Servilab. (2010). Fuentes estadísticas y explotación preliminar de la industria del ocio y la cultura en la Comunidad de Madrid. In. Madrid: Consejería de Hacienda de Madrid.

Spink, J., \& Moyer, D. C. (2011). Defining the public health threat of food fraud. Journal of Food Science, 76, 157-163.

Tinacci, L., Guidi, A., Toto, A., Guardone, L., Giusti, A., D'Amico, P., \& Armani, A. (2018). DNA barcoding for the verification of supplier's compliance in the seafood chain: How the lab can support companies in ensuring traceability. Italian journal of food safety, 7, 6894.

Triantafyllidis, A., Karaiskou, N., Perez, J., Martinez, J. L., Roca, A., Lopez, B., \& Garcia-Vazquez, E. (2010). Fish allergy risk derived from ambiguous vernacular fish names: forensic DNA-based detection in Greek markets. Food Research International, 43, 2214-2216.

von der Heyden, S., Barendse, J., Seebregts, A. J., \& Matthee, C. A. (2010). Misleading the masses: detection of mislabeled and substituted frozen fish products in South Africa. ICES Journal of Marine Science, 67, 176-185.

Ward, R. D., Holmes, B. H., \& Last, P. R. (2008). DNA barcoding Australasian chondrichthyans: results and potential uses in conservation. Marine and Freshwater Research, 59, 57-71. 


\section{Figure captions}

306 Fig. 1.- Proportion of Fish mislabeling (\%, black bars) with respect to the menu labels 307 detected in the present study (Y-axis, number of samples within brackets).

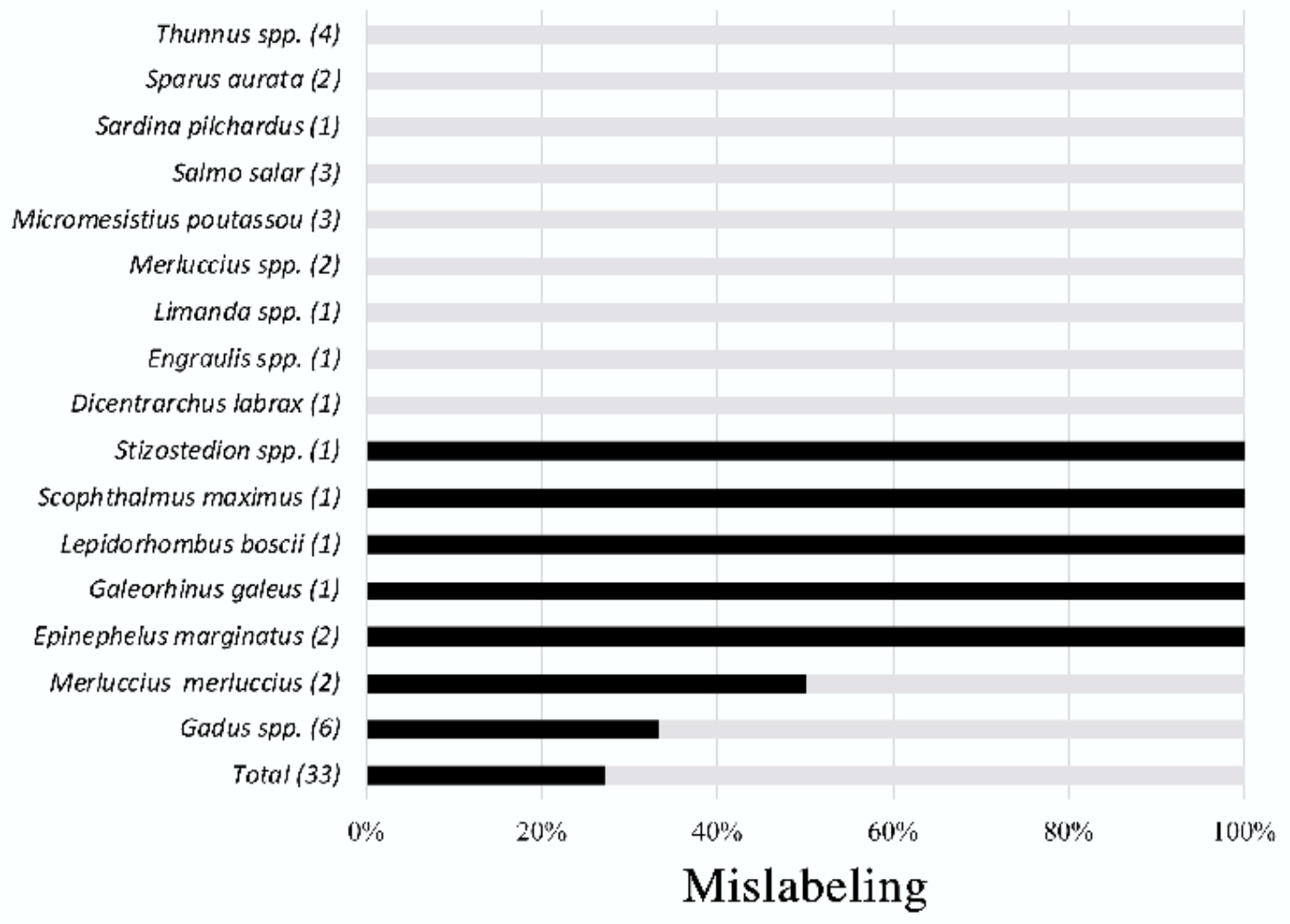


Table 1.- Fish and shark samples (S) obtained from restaurants (abbreviation: Rest) of eight different districts of Madrid, Spain. The table shows the Spanish (Menu name) and scientific name (Menu taxa) of the fish taxa mentioned on the Menu, the species identified by BLAST (https://www.ncbi.nlm.nih.gov/BLAST), and the similarity between the amplified and the most similar sequence existing in GeneBank (Sim, in $\%$ ). The presence of mislabeling was annotated with Yes in column (Mislab), and No indicated that menu name and BLAST species coincided. mentioned on the Menu (in \%) is shown between brackets in column "Sim".

\begin{tabular}{|c|c|c|c|c|c|c|c|}
\hline District & Rest & $\mathbf{S}$ & Menu name & Menu taxa & BLAST & Sim & Mislab \\
\hline Arganzuela & R45 & S67 & Corvina en escabeche & Argyrosomus regius & Thunnus sp., Katsuwonus pelamis & 99 & - \\
\hline Carabanchel & R2 & S3 & Atún & Thunnus spp. & Thunnus sp., Katsuwonus pelamis & 99 & - \\
\hline Carabanchel & R2 & S4 & Bacaladillas & Micromesistius poutassou & $\begin{array}{l}\text { Micromesistius poutassou, } M \text {. } \\
\text { australis }\end{array}$ & 100 & No \\
\hline Centro & R15 & $\mathrm{S} 25$ & Carpaccio de Atún & $\begin{array}{l}\text { Thunnus, Katsuwonus } \\
\text { pelamis }\end{array}$ & Gadus morhua, G. macrocephalus & 99 & - \\
\hline Centro & R16 & S26 & Tartar de atún & Thunnus spp. & Salmo salar & 99 & - \\
\hline Centro & R19 & S29 & Merluza & Merluccius merluccius & Merluccius paradoxus & 100 & No \\
\hline Centro & R20 & S30 & Mero & Epinephelus marginatus & Argyrosomus japonicus, A. amoyensis & 98 & - \\
\hline Centro & R21 & S31 & Bacalao & Gadus spp. & Gadus morhua, G. macrocephalus & 100 & No \\
\hline Centro & R23 & S34 & Pincho de bacalao & Gadus spp. & Gadus morhua, G. macrocephalus & 98 & - \\
\hline Centro & $\mathrm{R} 23$ & S35 & Pincho de salmón & Salmo salar & Salmo salar & 100 & No \\
\hline Centro & R24 & S36 & Salmón & Salmo salar & Salmo salar & 98 & - \\
\hline Centro & R24 & S37 & Merluza & Merluccius merluccius & Merluccius merluccius & 99 & - \\
\hline Centro & R31 & S45 & Salmón & Salmo salar & Salmo salar & 98 & - \\
\hline
\end{tabular}




\begin{tabular}{|c|c|c|c|c|c|c|c|}
\hline Centro & R32 & $\mathrm{S} 46$ & Bacalao & Gadus spp. & Gadus morhua, G. macrocephalus & 99 & - \\
\hline Centro & R36 & S52 & Salmón & Salmo salar & Salmo salar & 99 & - \\
\hline Centro & $\mathrm{R} 41$ & S61 & Lubina & Dicentrarchus labrax & Dicentrarchus labrax & 100 & No \\
\hline Centro & $\mathrm{R} 48$ & S71 & Bacalao & Gadus spp. & Thunnus sp., Katsuwonus pelamis & $100(86)$ & Yes \\
\hline Centro & R49 & $\mathrm{S} 72$ & Pescadilla & Merluccius spp. & Merluccius merluccius & 100 & No \\
\hline Centro & R50 & S73 & Merluza & Merluccius merluccius & Merluccius merluccius & 99 & - \\
\hline Centro & R53 & $\mathrm{S} 76$ & Salmón & Salmo salar & Salmo salar & 100 & No \\
\hline Centro & R53 & S77 & Mero & Epinephelus marginatus & Lates niloticus & $100(75)$ & Yes \\
\hline Chamartín & $\mathrm{R} 4$ & S6 & Cazón & Galeorhinus galeus & Thunnus sp., Katsuwonus pelamis & $100(93)$ & Yes \\
\hline Chamartín & R8 & $\mathrm{S} 10$ & Salmón & Salmo salar & $\begin{array}{l}\text { Oncorhynchus masou, O. tshawytscha, } \\
\text { O. keta }\end{array}$ & 99 & - \\
\hline Chamartín & R8 & $\mathrm{S} 11$ & Mero & Epinephelus marginatus & Pollachius virens & $100(97)$ & Yes \\
\hline Chamartín & R8 & $\mathrm{S} 12$ & Cazón & Galeorhinus galeus & Prionace glauca & 98 & - \\
\hline Chamartín & R8 & $\mathrm{S} 13$ & Atún & Thunnus spp. & Thunnus sp., Katsuwonus pelamis & 99 & - \\
\hline Chamartín & R8 & $\mathrm{S} 14$ & Bacalao & Gadus spp. & Gadus morhua, G. macrocephalus & 100 & No \\
\hline Chamartín & R8 & $\mathrm{S} 15$ & Salmón & Salmo salar & Oncorhynchus keta & 99 & - \\
\hline Chamartín & R8 & S16 & Pescadilla & Merluccius spp. & Merluccius merluccius & 99 & - \\
\hline Chamartín & $\mathrm{R} 14$ & $\mathrm{~S} 24$ & Merluza & Merluccius merluccius & Merluccius merluccius & 99 & - \\
\hline Chamartín & R38 & S57 & Tosta de sardina ahumada & Sardina pilchardus & Sardina pilchardus & 100 & No \\
\hline Chamartín & R38 & S58 & Ceviche de atún & Thunnus spp. & Thunnus sp., Katsuwonus pelamis & 100 & No \\
\hline Chamberí & $\mathrm{R} 10$ & $\mathrm{~S} 18$ & Sashimi de pez mantequilla & - & Lepidocybium flavobrunneum & 99 & - \\
\hline Chamberí & $\mathrm{R} 18$ & $\mathrm{~S} 28$ & Dados de Salmon & Salmo salar & Salmo salar & 99 & - \\
\hline Chamberí & R29 & $\mathrm{S} 43$ & Dorada & Sparus aurata & Sparus aurata & 100 & No \\
\hline Chamberí & R33 & $\mathrm{S} 47$ & Tartar de atún & Thunnus spp. & Thunnus sp., Katsuwonus pelamis & 99 & - \\
\hline Chamberí & $\mathrm{R} 42$ & S62 & Bacalao & Gadus spp. & Gadus morhua, G. macrocephalus & 99 & - \\
\hline Chamberí & $\mathrm{R} 43$ & S63 & Bacalao & Gadus spp. & Gadus morhua, G. macrocephalus & 100 & No \\
\hline
\end{tabular}




\begin{tabular}{|c|c|c|c|c|c|c|c|}
\hline Chamberí & $\mathrm{R} 46$ & S68 & Salmón & Salmo salar & Salmo salar & 99 & - \\
\hline Chamberí & R46 & S69 & Atún & Thunnus spp. & Thunnus sp., Katsuwonus pelamis & 100 & No \\
\hline Chamberí & $\mathrm{R} 47$ & $\mathrm{~S} 70$ & Nem de Bonito & Sarda sarda & Merluccius merluccius & 99 & - \\
\hline Chamberí & R51 & $\mathrm{S} 74$ & Cazón & Galeorhinus galeus & Prionace glauca & 98 & - \\
\hline Chamberí & R7 & S9 & Perca en ceviche & Stizostedion spp. & Lates niloticus & 98 & - \\
\hline Chamberí & R9 & $\mathrm{S} 17$ & Merluza & Merluccius merluccius & Merluccius merluccius & 99 & - \\
\hline Latina & R39 & S59 & Dorada & Sparus aurata & Sparus aurata & 100 & No \\
\hline Latina & $\mathrm{R} 40$ & S60 & Ceviche de perca & Stizostedion spp. & Thunnus sp., Katsuwonus pelamis & $100(75)$ & Yes \\
\hline Moncloa & R6 & S8 & Salmón & Salmo salar & Oncorhynchus keta & 99 & - \\
\hline Salamanca & R1 & $\mathrm{S} 1$ & Atún & Thunnus spp. & Thunnus sp., Katsuwonus pelamis & 98 & - \\
\hline Salamanca & R1 & $\mathrm{S} 2$ & Bacalao & Gadus spp. & Xiphias gladius & $100(81)$ & Yes \\
\hline Salamanca & R5 & $\mathrm{S} 7$ & Dorada & Sparus aurata & Sparus aurata & 98 & - \\
\hline Salamanca & $\mathrm{R} 12$ & $\mathrm{~S} 21$ & Gallo & Lepidorhombus boscii & Lepidorhombus whiffiagonis & $100(93)$ & Yes \\
\hline Salamanca & $\mathrm{R} 13$ & $\mathrm{~S} 22$ & Ensalada de ventresca & $\begin{array}{l}\text { Thunnus spp., } \\
\text { Katsuwonus pelamis }\end{array}$ & Thunnus sp., Katsuwonus pelamis & 98 & - \\
\hline Salamanca & $\mathrm{R} 13$ & $\mathrm{~S} 23$ & Cazón & Galeorhinus galeus & Prionace glauca & 98 & - \\
\hline Salamanca & $\mathrm{R} 25$ & S38 & Rodaballo & Scophthalmus maximus & Scophthalmus maximus & 99 & - \\
\hline Salamanca & R26 & S39 & Atún & Thunnus spp. & Thunnus sp., Katsuwonus pelamis & 98 & - \\
\hline Salamanca & R26 & $\mathrm{S} 40$ & Ventresca & $\begin{array}{l}\text { Thunnus spp., } \\
\text { Katsuwonus pelamis }\end{array}$ & Thunnus sp., Katsuwonus pelamis & 99 & - \\
\hline Salamanca & $\mathrm{R} 28$ & $\mathrm{~S} 42$ & Pescadilla & Merluccius spp. & Merluccius capensis & 99 & - \\
\hline Salamanca & R30 & S44 & Tartar de atún & Thunnus spp. & Thunnus sp., Katsuwonus pelamis & 100 & No \\
\hline Salamanca & $\mathrm{R} 34$ & $\mathrm{~S} 48$ & Tataki de atún & Thunnus spp. & Thunnus sp., Katsuwonus pelamis & 98 & - \\
\hline Salamanca & R34 & S49 & Ceviche de corvina & Argyrosomus regius & Argyrosomus japonicus, A. amoyensis & 98 & - \\
\hline Salamanca & R35 & $\mathrm{S} 50$ & Tataki de atún & Thunnus spp. & Thunnus sp., Katsuwonus pelamis & 100 & No \\
\hline Salamanca & R35 & S51 & Sashimi de salmón & Salmo salar & Salmo salar & 99 & - \\
\hline
\end{tabular}




\begin{tabular}{|c|c|c|c|c|c|c|c|}
\hline Salamanca & R37 & S53 & Limanda & Limanda spp. & Limanda aspera & 100 & No \\
\hline Salamanca & R37 & S54 & Bacaladillas & Micromesistius poutassou & $\begin{array}{l}\text { Micromesistius poutassou, } M . \\
\text { australis }\end{array}$ & 100 & No \\
\hline Salamanca & R37 & S55 & Salmón & Salmo salar & $\begin{array}{l}\text { Oncorhynchus masou, O. tshawytscha, } \\
\text { O. keta }\end{array}$ & 99 & - \\
\hline Salamanca & R37 & S56 & Pescadilla & Merluccius spp. & Merluccius merluccius & 100 & No \\
\hline Salamanca & R44 & S64 & Boquerones & Engraulis spp. & Engraulis encrasicolus, E. eurystole & 100 & No \\
\hline Salamanca & R44 & S65 & Bacaladillas & Micromesistius poutassou & $\begin{array}{l}\text { Micromesistius poutassou, } M . \\
\text { australis }\end{array}$ & 100 & No \\
\hline Salamanca & R44 & S66 & Rodaballo & Scophthalmus maximus & Pleuronectes punctatissimus & $100(78)$ & Yes \\
\hline Salamanca & R52 & S75 & Lomos de Merluza & Merluccius merluccius & Merluccius paradoxus & 99 & - \\
\hline Tetuán & R3 & S5 & Sargo & Diplodus sargus & Diplodus sargus & 99 & - \\
\hline Tetuán & R11 & S19 & Pez mantequilla & - & Ruvettus pretiosus & 100 & - \\
\hline Tetuán & R11 & S20 & Merluza & Merluccius merluccius & Merluccius merluccius & 99 & - \\
\hline Tetuán & R17 & S27 & Merluza & Merluccius merluccius & Thunnus sp., Katsuwonus pelamis & $100(96)$ & Yes \\
\hline Tetuán & R22 & S32 & Salmón & Salmo salar & Salmo salar & 100 & No \\
\hline Tetuán & R22 & S33 & Bacalao & Gadus spp. & Gadus morhua, G. macrocephalus & 100 & No \\
\hline Tetuán & R27 & S41 & Emperador & Xiphias gladius & Dicentrarchus labrax & 98 & - \\
\hline
\end{tabular}


